\title{
Amyloid- $\beta$ Decreases Cell-Surface AMPA Receptors by Increasing Intracellular Calcium and Phosphorylation of GluR2
}

\author{
Shi-Jie Liu, Robert Gasperini, Lisa Foa and David Henry Small* \\ Menzies Research Institute, University of Tasmania, Hobart, Tasmania, Australia
}

Handling Associate Editor: D. Allan Butterfield

Accepted 15 April 2010

\begin{abstract}
Amino-3-hydroxy-5-methyl-4-isoxazole-propionic acid receptors (AMPARs) are key regulators of synaptic function and cognition. In Alzheimer's disease (AD), cell-surface AMPARs are downregulated, however the reason for this downregulation is not clear. In the present study, we found that $\mathrm{A} \beta$ significantly decreased levels of the cell-surface AMPA-type glutamate receptor subunit 2 (GluR2), and increased the concentration of free cytosolic calcium ion $\left(\left[\mathrm{Ca}^{2+}\right]_{i}\right)$ in hippocampal neurons. Ion channel blockers (nifedipine, tetrodotoxin, SKF96365) decreased $\left[\mathrm{Ca}^{2+}\right]_{i}$ and increased the level of cell-surface GluR2, whereas Bay K 8644, an activator of L-type voltage-gated calcium channels increased $\left[\mathrm{Ca}^{2+}\right]_{i}$ and decreased cell-surface GluR2. A $\beta$ and Bay K 8644 increased phosphorylation of serine-880 (S880) on GluR2, whereas the nifedipine. tetrodotoxin and SKF96365 decreased S880 phosphorylation. Finally, we found that bisindolylmeimide I (GF 109203X, GFX), an inhibitor of protein kinase $\mathrm{C}$ (PKC) blocked both the decrease in cell-surface GluR2 and the increase in phospho-S880 induced by A $\beta$ and Bay K 8644 . Taken together, these results demonstrate that $\mathrm{A} \beta$ decreases cell-surface GluR2 by increasing PKC-mediated phosphorylation of S880. Our study supports the view that a rise in cytosolic $\left[\mathrm{Ca}^{2+}\right]_{i}$ induced by $\mathrm{A} \beta$ could impair synaptic function by decreasing the availability of AMPARs at the synapse. This decrease in AMPARs may contribute to the decline in cognitive function seen in $\mathrm{AD}$.
\end{abstract}

Keywords: Alzheimer's disease, AMPA, amyloid- $\beta$, calcium, GluR2, phospho-GluR2, PKC

\section{INTRODUCTION}

Alzheimer's disease (AD) is the most common form of dementia in the elderly. It is estimated that 35 million people worldwide suffer from $\mathrm{AD}$ and that this number will increase four-fold by 2050. AD is characterized by two major pathological hallmarks: neurofibrillary tangles and neuritic plaques [1]. Neuritic plaques contain the amyloid- $\beta$ protein $(\mathrm{A} \beta)$, which is thought to play a crucial role in the etiology of $\mathrm{AD}[1]$. $\mathrm{A} \beta$ can

\footnotetext{
*Correspondence to: Professor David H. Small, Menzies Research Institute, University of Tasmania, Hobart, Tasmania 7001, Australia. Tel.: +61 36226 7348; Fax: +61 36226 7704; E-mail: d.h.small@menzies.utas.edu.au.
}

induce a number of biochemical changes in cells including an increase in levels of cytosolic calcium [2] and the stimulation of kinases, such as glycogen synthase kinase-3 $\beta$ (GSK-3 $\beta$ ) [3] and cyclin-dependent kinase-5 (CDK-5) [4], which contribute to the hyperphosphorylation of tau. Recently, it has been reported that $\mathrm{A} \beta$ deposits can impair default network function in older individuals even without clinical dementia symptoms [5]. Thus, $\mathrm{A} \beta$ may impair the function of neurons at an early stage in the development of AD.

Synaptic plasticity is a key component of memory and cognition, which regulates the strength of signaling between neurons [6]. Synaptic plasticity can be mediated by changes in the level of receptors on both pre- and post-synaptic membranes [6]. $\alpha$-Amino- 
3-hydroxy-5-methyl-4-isoxazole-propionic acid receptors (AMPARs) are ligand-gated ion channels, which are important regulators of synaptic plasticity [7,8]. AMPARs are inserted into the post-synaptic membrane during long-term potentiation (LTP) and they are removed from the membrane during long-term depression (LTD) [7].

AMPARs may contain four different AMPA-type glutamate receptor subunits (GluR1-4), which are assembled into a heterotetrameric complex, containing GluR2 and either GluR1, GluR3 or GluR4 [7]. The number of AMPARs decreases with age in amyloid$\beta$ protein precursor $(\mathrm{A} \beta \mathrm{PP})$ transgenic mice, and this decrease is correlated with a decrease in AMPAR currents [9-11]. A $\beta$ may downregulate the level of GluR1 and GluR2 on the cell surface [12]. However, the mechanism of this downregulation has not been elucidated. A recent study suggests that $\mathrm{A} \beta$ decreases cell-surface GluR1 by inhibiting $\mathrm{Ca}^{2+} /$ calmodulin-dependent protein kinase II (CaMKII) [13]. However, AMPAR trafficking between the cell-surface and the cytoplasm is also known to be regulated by phosphorylation of GluR2 [7,14]. Serine-880 (S880) of GluR2 can phosphorylated by protein kinase $\mathrm{C}$ (PKC) and this phosphorylation leads to the removal of GluR2 from the cell surface $[15,16]$. Therefore, we hypothesized that A $\beta$ may stimulate PKC to phosphorylate GluR2 and thereby downregulate AMPARs on the cell-surface.

In the present study, we report that $\mathrm{A} \beta$ increases the level of cytosolic calcium in hippocampal neurons, and also increases phospho-S880 on GluR2. Our study suggests that $\mathrm{A} \beta$-mediated effects on GluR2 phosphorylation could alter AMPAR activity and thereby attenuate synaptic activity.

\section{MATERIALS AND METHODS}

\section{Materials}

A rabbit polyclonal immunoglobulin $\mathrm{G}$ ( $\mathrm{IgG})$ (ab40878) which recognizes the N-terminus of GluR2 and a rabbit polyclonal antibody (ab52180) which recognizes GluR2 phosphorylated at S880 (anti-P-S880) were purchased from Abcam (Cambridge, UK) [13]. A mouse monoclonal $\mathrm{IgG}$ which recognizes the Nterminus of GluR2 (MAB397) was purchased from Millipore Bioscience Research Reagents (Temecula, CA). Anti-A $\beta$ monoclonal antibody (6E10) was from Covance (Princeton, NJ). Nifedipine, trypsin, TritonX100, Nonidet P-40 (NP-40), sodium deoxycholate
(DOC), sodium dodecyl sulfate (SDS) and poly-Dlysine-hydrobromide were purchased from SigmaAldrich Inc. (Saint Louis, MO). Cholera toxin B subunit conjugated to Alexa Fluor 594 was purchased from Molecular Probes (Eugene, OR). All A $\beta$ peptides were purchased from rPeptide (Athens, GA). GF 109203X (GFX, bisindolylmaleimide I) was purchased from Merck KGaA (Darmstadt, Germany). Tetrodotoxin (TTX) and Bay K 8644 (Bay K) were purchased from Alamone Labs. (Jerusalem, Israel). SKF96365 (SKF) was purchased from Tocris Bioscience (Bristol, UK). Streptavidin-agarose beads and Fluo-4/AM were purchased from Invitrogen (Carlsbad, CA). Sulfo-NHSLC-Biotin and CL-X-films were from Thermo Scientific (Rockford, IL). Enhanced chemiluminescence detection kit was purchased from Millipore Corporation (Billerica, MA).

\section{Preparation of hippocampal neurons}

Dissociated hippocampal neurons were prepared from postnatal day 0 (P0) C57 mice using a modified protocol for rat tissue [17]. Hippocampi were dissected, digested by trypsin, the tissue was disrupted by trituration to produce isolated cells, and then the cells were seeded either on coverslips or directly on 6-well plates which had been previously coated with poly-D-lysine ( $10^{6}$ cells/well). The cultures prepared by this method contained at least $80 \%$ neurons and were used at $14 \mathrm{~d}$ in vitro (DIV) for all experiments.

\section{Preparation of A $\beta$ peptides}

$\mathrm{A} \beta$ peptides were dissolved at a concentration of $1 \mathrm{mM}$ in dimethyl sulfoxide to make a stock solution that was stored in $-80^{\circ} \mathrm{C}$. After thawing stocks at $37^{\circ} \mathrm{C}$, the $\mathrm{A} \beta$ solutions were diluted with culture medium to yield a final concentration of $1 \mu \mathrm{M}$ and then used in immediately for all experiments. To analyze $\mathrm{A} \beta$ oligomers by western blotting, $24 \mu \mathrm{l}$ of freshly prepared $\mathrm{A} \beta$ in culture medium was combined with $8 \mu$ l of $4 \times$ sample buffer (250 mM Tris-HCl, pH 6.8, 8\% sodium dodecyl sulfate, $40 \%$, v/v, glycerol, $0.02 \%$, w/v, bromophenol blue and $10 \%(\mathrm{v} / \mathrm{v}) \beta$-mercaptoethanol) and boiled for 5 min. Samples $(20 \mu \mathrm{l})$ were loaded onto $16.5 \%$ Tristricine gels for electrophoresis. Proteins were then electrophoretically transferred onto $0.22 \mu \mathrm{m}$ nitrocellulose membranes, the membranes were air dried, boiled in phosphate-buffered saline $(20 \mathrm{mM}$ sodium phosphate buffer, pH 7.4, containing $150 \mathrm{mM} \mathrm{NaCl}$ ) for $5 \mathrm{~min}$. The nitrocellulose membranes were incubated with an 
anti-A $\beta$ antibody (6E10, 1:1000 dilution) followed by a secondary peroxidase-conjugated anti-mouse IgG antibody (1:4000 dilution) and then bands were visualized by enhanced chemiluminescence on CL-X-ray film.

\section{Measurement of cell-surface GluR2}

Cell-surface proteins were labeled with biotin and cell-surface GluR2 was quantified as previously described [18]. Primary hippocampal neurons were washed three times with ice-cold PBS (pH 7.4) containing $1 \mathrm{mM} \mathrm{CaCl}_{2}, 1.3 \mathrm{mM} \mathrm{MgCl}$ (PBS-Ca-Mg) on ice, and incubated with $1 \mathrm{mg} / \mathrm{ml}$ sulfo-NHS-LCBiotin in PBS-Ca-Mg for $20 \mathrm{~min}$ at $4{ }^{\circ} \mathrm{C}$. Then, cells were rinsed in $100 \mathrm{mM}$ glycine on ice to quench the biotin reaction and lysed in $500 \mu \mathrm{l}$ of PBS containing $0.5 \%$ DOC (w/v), $0.5 \%$ NP-40 (v/v), $0.2 \%$ SDS (w/v), and a cocktail of protease inhibitors (Roche Applied Science, Mannheim, Germany) and phosphatase inhibitors ( $20 \mathrm{mM}$ sodium $\beta$-glycerophosphate, $2 \mathrm{mM}$ $\mathrm{Na}_{3} \mathrm{VO}_{4}, 10 \mathrm{mM} \mathrm{NaF}, 5 \mathrm{mM} \mathrm{Na} \mathrm{P}_{2} \mathrm{O}_{7}$ ). The lysates were centrifuged at $13,000 \times \mathrm{g}$ for $15 \mathrm{~min}$ at $4{ }^{\circ} \mathrm{C}$ in a Heraeus Biofuge pico (DJB Labcare Ltd, Buckinghamshire, UK). An aliquot $(100 \mu \mathrm{l})$ of the resulting supernatant fraction was removed to measure protein by $D C$ protein assay kit (Bio-Rad Laboratories, Gladesville, NSW, Australia), and the remaining supernatant fraction was incubated with $30 \mu \mathrm{l}$ streptavidinagarose beads overnight at $4^{\circ} \mathrm{C}$. The beads were centrifuged $\left(500 \times \mathrm{g}, 5 \mathrm{~min}, 4^{\circ} \mathrm{C}\right)$ and then washed three times with lysis buffer, before being resuspended in $35 \mu 1$ SDS sample buffer and boiled for $10 \mathrm{~min}$. Western blotting was performed using anti-GluR2 (1:1000 dilution) or anti-P-S880 antibodies (1:1000 dilution). Bands were visualized by enhanced chemiluminescence and exposed on CL-X-ray film. Bands were scanned and the mean intensity of bands was quantified using NIH Image J software [19]. The ratio of immunoreactivity (I.R.) associated with cell-surface GluR2 to total GluR2 and P-S880 to total GluR2 was calculated and the results were expressed as a percentage of the average control value.

\section{Immunofluorescence staining}

Surface GluR2 was visualized in 14-DIV hippocampal cultures as previously described [20]. Cells were grown on poly-D-lysine-coated coverslips. After treatment with vehicle or drugs, the cells were chilled on ice, incubated with anti-GluR2 antibody (1:250 dilution) in culture medium for $20 \mathrm{~min}$, washed three times with ice-cold PBS and fixed for 10 min with $4 \%$ paraformaldehyde. All staining was performed at the same time and with the same batch of chemicals. To visualize the cell surface, Alexa 594-labelled Cholera toxin B subunit (1:3000 dilution) was also added with the anti-GluR2 antibody into the medium. Cells were permeabilized with $0.1 \%$ (v/v) Triton-X100, blocked with $5 \%(\mathrm{v} / \mathrm{v})$ goat serum in PBS, and then incubated with anti-P-S880 (1:300 dilution) in 5\% goat serum for $2 \mathrm{~h}$ at room temperature. Primary antibody staining was visualized using an anti-mouse Alexa 488 antibody (for the cell-surface anti-GluR2 antibody) or an antirabbit Alexa 594 antibody (for anti-P-S880). Fluorescence was viewed with an Olympus BX-50 microscope equipped with an UplanSAPO $60 \times$ oil immersion objective, and images were acquired with a Magnafire CCD camera (Optronics, Goleta, CA). Mean pixel intensity of the region of interest (ROI) encompassing the cell body and neurites was quantitated with NIH Image $\mathbf{J}$ [19] and data were expressed as ratio of the fluorescence of surface GluR2 to cholera toxin B subunit or surface GluR2 to phospho-S880.

\section{Measurement of concentration of free cytosolic calcium ion $\left(\left[\mathrm{Ca}^{2+}\right]_{i}\right)$}

Cells cultured in 96-well plates were incubated for $10 \mathrm{~min}$ at $37^{\circ} \mathrm{C}$ with $2 \mu \mathrm{M}$ Fluo-4/AM in culture medium. The medium containing Fluo-4/AM was removed and cells were washed twice with Tyrode's buffer $(129 \mathrm{mM} \mathrm{NaCl}, 5 \mathrm{mM} \mathrm{KCl}, 2 \mathrm{mM} \mathrm{CaCl}$, $1 \mathrm{mM} \mathrm{MgCl}_{2}, 30 \mathrm{mM}$ glucose, $25 \mathrm{mM}$ HEPES-NaOH, $\mathrm{pH} \mathrm{7.4)}$ at $37^{\circ} \mathrm{C}$. Fluorescence was measured on a Fluostar Optima plate reader (BMG Labtech $\mathrm{GmbH}$, Offenburg, Germany). The excitation wavelength was $485 \mathrm{~nm}$ and the fluorescence emission was monitored at a wavelength of $520 \mathrm{~nm}$. Changes in fluorescence were used as an index of changes in $\left[\mathrm{Ca}^{2+}\right]_{i}$. The ratio $\Delta \mathrm{F} / \mathrm{F}_{0}$ was calculated according to the formula $\Delta \mathrm{F} / \mathrm{F}_{0}=(\mathrm{F}-$ $\left.F_{0}\right) / F_{0}$, where $F$ is the fluorescence intensity of calcium and $F_{0}$ is average the fluorescence intensity before stimulation [21].

\section{Statistical analysis}

Statistical comparisons were made using one-way analysis of variance and a Least Significant Difference (LSD) post hoc test. A P value of 0.05 was used to determine statistical significance. Data were expressed at means \pm S.E.M. Statistical analysis was performed with SPSS 10.00 software. All experiments were repeated 3 times with similar results in each experiment. 
A
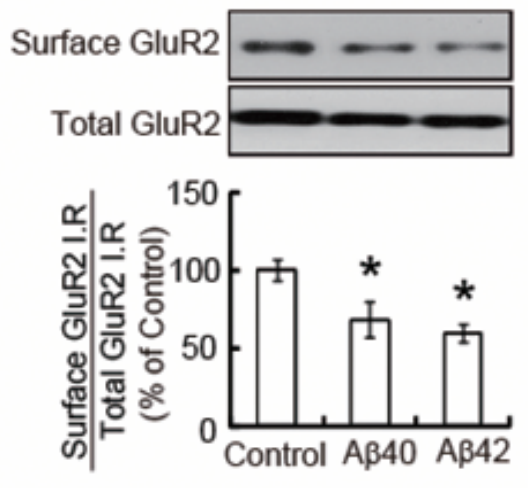

C
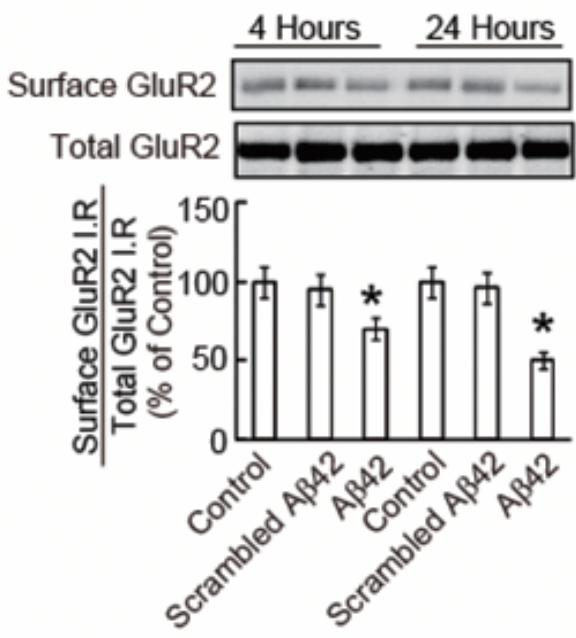

B

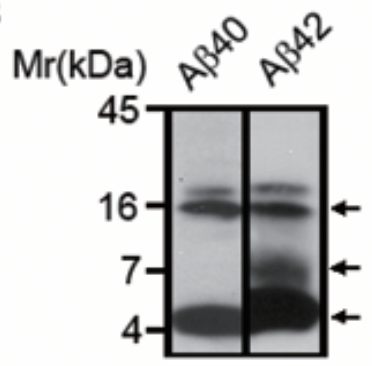

D
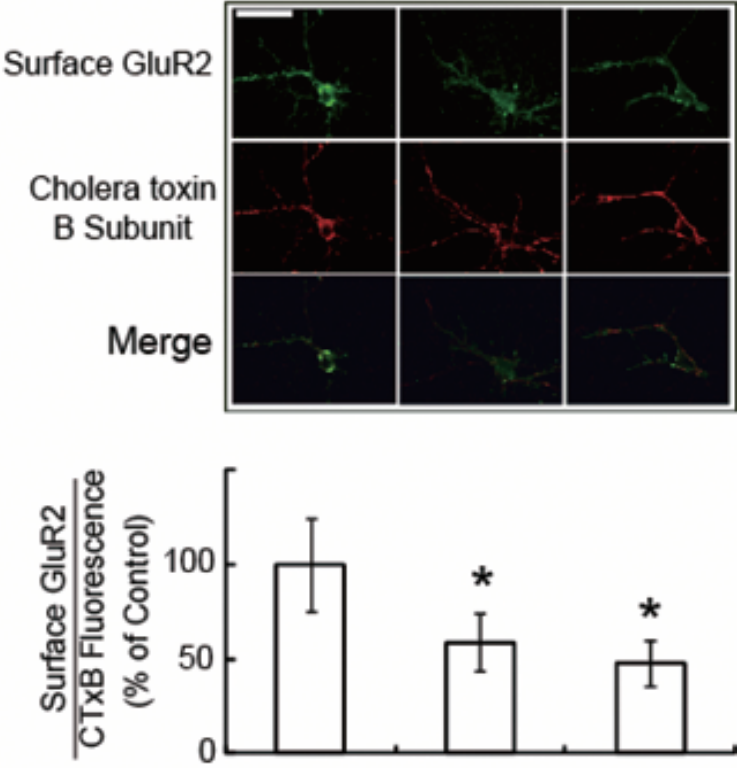

Fig. 1. A $\beta$ reduces cell-surface GluR2 in primary cultured hippocampal neurons. A) Cell-surface proteins were labeled with biotin, affinity-purified using streptavidin-agarose, and then western blotting was performed with an anti-GluR2 antibody. After $24 \mathrm{~h}$ of incubation, A $\beta_{40}$ and A $\beta_{42}$ (both $1 \mu \mathrm{M}$ ) significantly reduced the cell-surface GluR2 immunoreactivity (I.R), but not total GluR2 I.R. ( $n=6$ independent incubations, ${ }^{*} p<$ $0.05)$. B) Western blotting of freshly prepared $\mathrm{A} \beta_{40}$ and $\mathrm{A} \beta_{42}$ diluted into culture medium showed that both preparations of peptide contained oligomeric species. Arrows show expected positions of monomers (4 kDa), dimers ( $8 \mathrm{kDa})$ and tetramers $(16 \mathrm{kDa})$. C) The effect of A $\beta_{42}$ on cell-surface GluR2 was seen both at $4 \mathrm{~h}$ and $24 \mathrm{~h}$ after incubation. A scrambled sequence peptide (Scrambled A $\beta_{42}$ ) did not influence the amount of cell-surface GluR2 I.R. ( $n=6$ independent incubations, ${ }^{*} p<0.05$ ). D) Immunofluorescence microscopy of cell-surface GluR2 (green) also showed that there was a reduction in the level of cell-surface GluR2 by $1 \mu \mathrm{M} \mathrm{A} \beta_{40}$ and A $\beta_{42}$ after $24 \mathrm{~h}$ incubation ${ }^{*} p<0.05, n=10$ cells, compared with control). Cholera toxin B subunit was used as a cell-surface marker. Scale bar $=50 \mu \mathrm{m}$.

\section{RESULTS}

\section{A $\beta$ decreases cell-surface GluR2}

We first investigated the effects of $\mathrm{A} \beta$ on cell-surface GluR2. Primary hippocampal neurons were prepared and cultured for 14 DIV, after which the cells were treated for $24 \mathrm{~h}$ with freshly prepared $\mathrm{A} \beta_{40}$ or $\mathrm{A} \beta_{42}$ $(1 \mu \mathrm{M})$. Using a biotinylation approach to measure cellsurface GluR2, we found that $\mathrm{A} \beta_{40}$ and $\mathrm{A} \beta_{42}$ signif- icantly decreased cell-surface GluR2 immunoreactivity to approximately $70 \%$ and $60 \%$ of control values, respectively. There was no significant change in the level of total GluR2 in the cells after the $\mathrm{A} \beta$ treatment (Fig. 1A). As oligomeric $\mathrm{A} \beta$ is generally considered to be the most toxic form of the peptide, we investigated whether oligomers were present in our $\mathrm{A} \beta$ preparation. The culture medium was analyzed after addition of $\mathrm{A} \beta$ by electrophoresis on a $16.5 \%$ SDS-Tris-tricine gel followed by western blotting for $\mathrm{A} \beta$ with a monclonal an- 

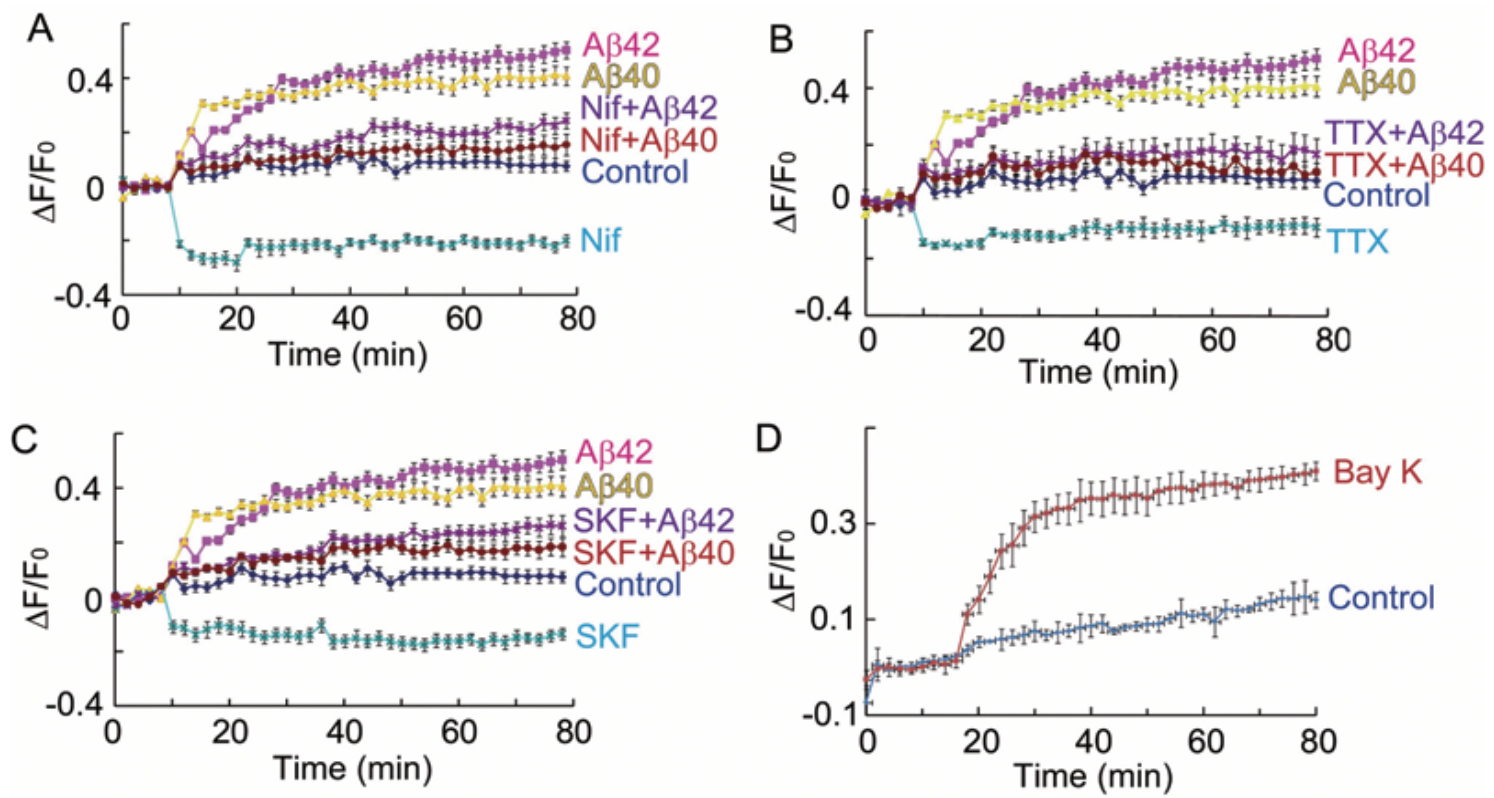

Fig. 2. $\mathrm{A} \beta$ and Bay $\mathrm{K}$ increase $\left[\mathrm{Ca}^{2+}\right]_{i}$, whereas nifedipine, TTX and SKF decrease $\left[\mathrm{Ca}^{2+}\right]_{i}$ in hippocampal neurons. Figure shows the time course of $\mathrm{Ca}^{2+}$ fluorescence changes $\left(\Delta \mathrm{F} / \mathrm{F}_{0}\right)$. Drugs and $\mathrm{A} \beta$ were added at 10 min. A) Effect of nifedipine $(5 \mu \mathrm{M}), \mathrm{A} \beta_{40}(1 \mu \mathrm{M})$, and $\mathrm{A} \beta_{42}$ $(1 \mu \mathrm{M})$. B) Effect of TTX $(5 \mu \mathrm{M}), \mathrm{A} \beta_{40}(1 \mu \mathrm{M})$, and $\mathrm{A} \beta_{42}(1 \mu \mathrm{M})$. C) Effect of SKF $(5 \mu \mathrm{M}), \mathrm{A} \beta_{40}(1 \mu \mathrm{M})$, and $\mathrm{A} \beta_{42}(1 \mu \mathrm{M})$. D) Effect of Bay $\mathrm{K}(1 \mu \mathrm{M}), \mathrm{A} \beta_{40}(1 \mu \mathrm{M})$, and $\mathrm{A} \beta_{42}(1 \mu \mathrm{M})$. Values are means \pm S.E.M. $(n=6)$.

tibody (6E10). We found that although most of $A \beta$ immunoreactivity migrated in the position of monomeric $\mathrm{A} \beta$, small amounts of oligomeric $\mathrm{A} \beta$ were also present in both the $\mathrm{A} \beta_{40}$ and $\mathrm{A} \beta_{42}$ preparations. The apparent molecular mass of the oligomeric species was consistent with their being dimers $(8 \mathrm{kDa})$ and tetramers (16 kDa) of $\mathrm{A} \beta$ (Fig. 1B).

To examine the specificity of the effect of $\mathrm{A} \beta$ on GluR2, we also investigated the effects of a scrambled A $\beta$ peptide on cell-surface GluR2 levels. Primary hippocampal neurons were incubated for 4 or $24 \mathrm{~h}$ with freshly prepared $\mathrm{A} \beta_{42}(1 \mu \mathrm{M})$ or a scrambled sequence $\mathrm{A} \beta_{42}$ peptide $(1 \mu \mathrm{M})$. We found that the scrambled peptide did not significantly alter total GluR2 or cell-surface GluR2, either after 4 or $24 \mathrm{~h}$ of incubation. However, $\mathrm{A} \beta_{42}$ significantly decreased the surface GluR2, but not total GluR2, at both the 4 and $24 \mathrm{~h}$ time points (Fig. 1C).

We also examined the level of GluR2 on the cell surface by immunofluorescence microscopy using an antibody that recognizes a region at the $\mathrm{N}$-terminus of GluR2 within the extracellular domain. A fluorescently tagged cholera toxin B subunit was used to control for the amount of cell-surface membrane. In agreement with results from the biotin-labeling experiment, we found that $1 \mu \mathrm{M} \mathrm{A} \beta_{40}$ or $\mathrm{A} \beta_{42}$ significantly decreased cell-surface GluR2 as measured by the ratio of cell-surface GluR2 to cholera B subunit fluorescence (Fig. 1D).

\section{Cytosolic calcium regulates cell-surface GluR2}

Cytosolic calcium is an important second messenger that plays a key role in regulating cell-surface AMPARs [20]. As $\mathrm{A} \beta$ is known to alter calcium levels in neurons [2], we investigated the role of calcium and $\mathrm{A} \beta$ on levels of cell-surface GluR2. In these experiments, we measured $\left[\mathrm{Ca}^{2+}\right]_{i}$ using the fluorescent calcium indicator Fluo-4 and we examined the effects of $\mathrm{A} \beta$, channel blockers and agonists on $\left[\mathrm{Ca}^{2+}\right]_{i}$ (Fig. 2) and on the level of cell-surface GluR2 (Fig. 3).

$\mathrm{A} \beta_{40}$ and $\mathrm{A} \beta_{42}$ (both incubated at a concentration of $1 \mu \mathrm{M})$ significantly increased $\left[\mathrm{Ca}^{2+}\right]_{i}$ (Fig. $2 \mathrm{~A}$ ). Experiments with channel blockers supported the view that calcium is a key regulator of cell-surface GluR2. We found that drugs which lowered $\left[\mathrm{Ca}^{2+}\right]_{i}$ all increased the level of cell-surface GluR2. First, we investigated the effects of nifedipine, an L-type voltagegated calcium channel blocker. Nifedipine $(5 \mu \mathrm{M})$ significantly depressed calcium both in the presence and absence of $\mathrm{A} \beta$ (Fig. 2A). Nifedipine also significantly increased cell-surface GluR2 both in the absence and presence of $\mathrm{A} \beta$ (Fig. 3A). Like nifedipine, TTX (5 $\mu \mathrm{M})$, a voltage-gated sodium channel blocker, de- 

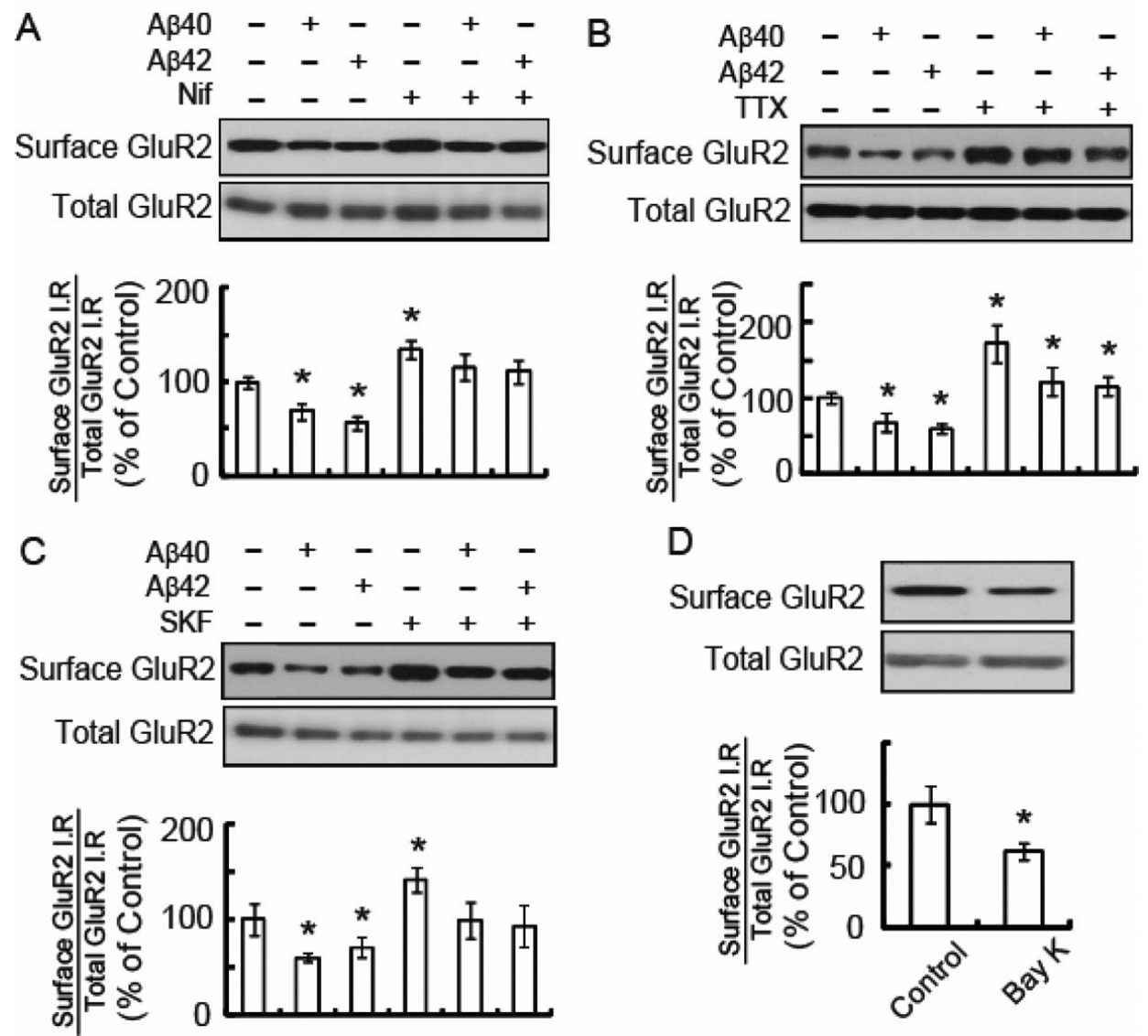

Fig. 3. A $\beta$ peptides decrease cell-surface GluR2, whereas nifedipine, SKF and TTX increase cell-surface GluR2. Cell-surface proteins were labeled with biotin, affinity-purified using streptavidin-agarose, and then western blotting was performed with an anti-GluR2 antibody. Figure shows a representative western blot for each experiment and quantitation of cell surface GluR2 and total GluR2 immunoreactivity (I.R.). A) Effect of nifedipine $(5 \mu \mathrm{M}) \mathrm{A} \beta_{40}$ and $\mathrm{A} \beta_{42}(1 \mu \mathrm{M})$. B) Effect of TTX $(5 \mu \mathrm{M}), \mathrm{A} \beta_{40}(1 \mu \mathrm{M})$, and A $\beta_{42}(1 \mu \mathrm{M})$. C) Effect of SKF $(5 \mu \mathrm{M})$, $\mathrm{A} \beta_{40}(1 \mu \mathrm{M})$, and $\mathrm{A} \beta_{42}(1 \mu \mathrm{M})$. D) Effect of Bay $\mathrm{K}(1 \mu \mathrm{M}), \mathrm{A} \beta_{40}(1 \mu \mathrm{M})$, and $\mathrm{A} \beta_{42}(1 \mu \mathrm{M}) .\left(n=6\right.$ independent incubations, $\left.{ }^{*} p<0.05\right)$.

pressed $\left[\mathrm{Ca}^{2+}\right]_{i}$ (Fig. 2B) and increased cell-surface GluR2 (Fig. 3B) both in the absence and presence of $\mathrm{A} \beta$. SKF $(5 \mu \mathrm{M})$, a non-selective cation channel blocker, also significantly decreased $\left[\mathrm{Ca}^{2+}\right]_{i}$ (Fig. 2C) and increased cell-surface GluR2 (Fig. 3C) both in the absence and presence of $\mathrm{A} \beta$. Finally, to verify the central role of calcium on cell-surface GluR2, we examined the effect of Bay K, an activator of L-type voltage-gated calcium channels. We found that $1 \mu \mathrm{M}$ Bay $\mathrm{K}$ significantly increased calcium (Fig. 2D), and decreased cell-surface GluR2 (Fig. 3D), both in the presence and absence of $\mathrm{A} \beta$.

Although our results suggested that $\mathrm{A} \beta$ reduces cellsurface GluR2 by increasing $\left[\mathrm{Ca}^{2+}\right]_{i}$, we found no evidence that the effect of $\mathrm{A} \beta$ was mediated directly via L-type voltage-gated calcium channels, voltage-gated sodium channels or SKF-sensitive non-selective cation channels as the effect of $\mathrm{A} \beta$ on calcium or cell-surface GluR2 was not blocked by any of the channel blockers.

\section{A $\beta$ increases phosphorylation of $S 880$ in GluR2}

Phosphorylation of GluR2 on the C-terminus regulates trafficking of GluR2 between the cell surface and the cytoplasm [14-16]. Phosphorylation at S880 induces endocytosis of GluR2 and results in a decrease in cell-surface GluR2 [15,16]. To elucidate the mechanism by which $\mathrm{A} \beta$ reduced cell-surface GluR2, we analyzed the phosphorylation of GluR2 using a phosphoS880-specific antibody. We found that $1 \mu \mathrm{M} \mathrm{A} \beta_{40}$ or $1 \mu \mathrm{M} \mathrm{A} \beta_{42}$ significantly increased phospho-S880 immunoreactivity to approximately $230 \%$ of control values, supporting the view that $\mathrm{A} \beta$ increases phosphorylation of S880 on GluR2 (Fig. 4B). This effect on S880 phosphorylation was observed both at $4 \mathrm{hr}$ and 
A
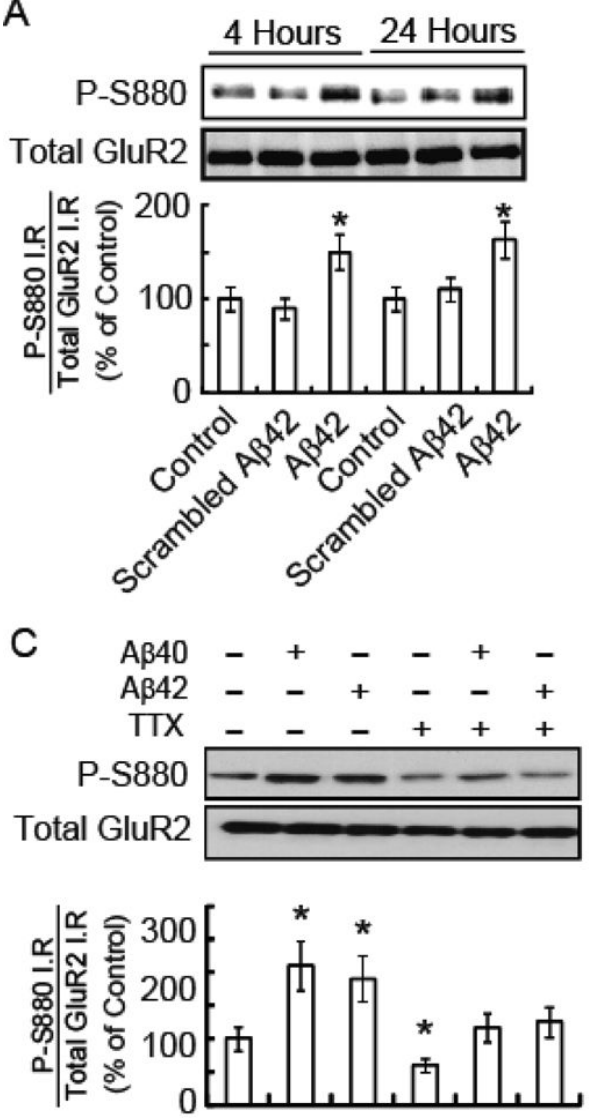
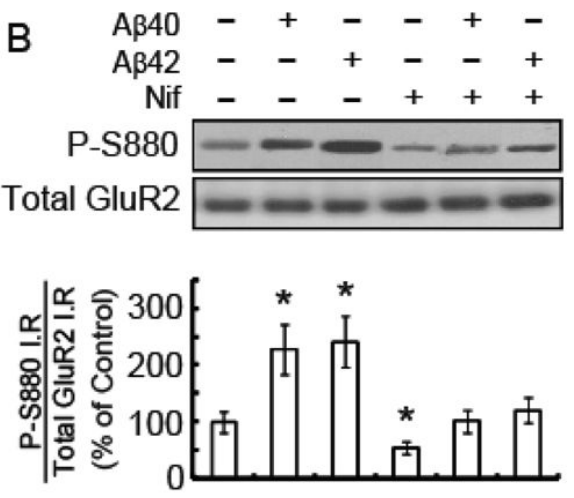
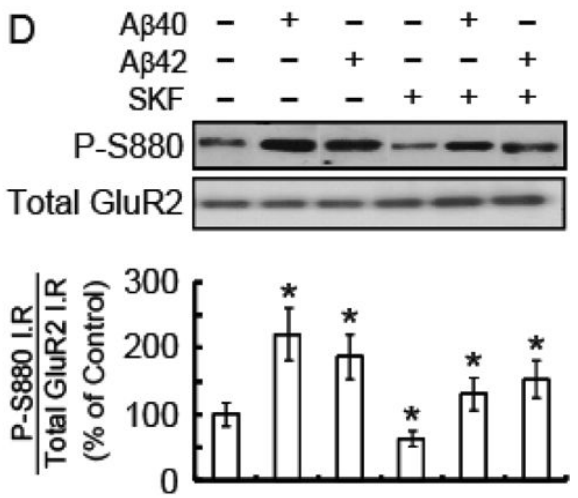

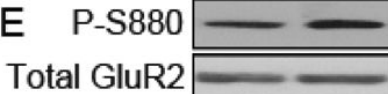

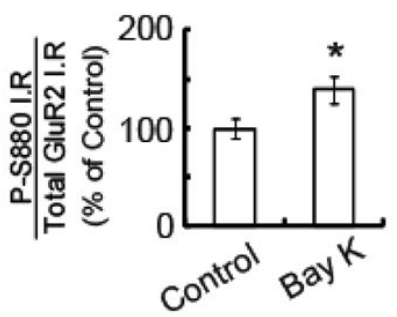

Fig. 4. $\mathrm{A} \beta$ and Bay $\mathrm{K}$ increase while ion-channel blockers decrease phospho-S880 immunoreactivity. Figure shows a representative western blot and quantitation of phospho-S880 (P-S88) and total GluR2 immunoreactivity (I.R.) $\left(n=6\right.$ independent incubations, $\left.{ }^{*} p<0.05\right)$. A) A $\beta_{42}$ $(1 \mu \mathrm{M})$ significantly increased the phospho-S880 I.R. both at 4 and $24 \mathrm{~h}$ after incubation. Scrambled A $\beta_{42}$ peptide $(1 \mu \mathrm{M})$ did not influence phospho-S880 I.R. ( $n=6$ independent incubations, $\left.{ }^{*} p<0.05\right)$. In panels B-E, levels of phospho-S880 I.R. and total GluR2 I.R. were measured $24 \mathrm{~h}$ after addition of drugs and $\mathrm{A} \beta$ peptides. B) Effect of nifedipine $(5 \mu \mathrm{M}), \mathrm{A} \beta_{40}(1 \mu \mathrm{M}), \mathrm{A} \beta_{42}(1 \mu \mathrm{M})$ on P-S880 I.R. C) Effect of TTX $(5 \mu \mathrm{M}), \mathrm{A} \beta_{40}(1 \mu \mathrm{M})$, and $\mathrm{A} \beta_{42}(1 \mu \mathrm{M})$. D) Effect of SKF $(5 \mu \mathrm{M}), \mathrm{A} \beta_{40}(1 \mu \mathrm{M})$, and $\mathrm{A} \beta_{42}(1 \mu \mathrm{M})$. E) Effect of Bay K $(1 \mu \mathrm{M}), \mathrm{A} \beta_{40}(1 \mu \mathrm{M})$, and $\mathrm{A} \beta_{42}(1 \mu \mathrm{M})$.

$24 \mathrm{hr}$ after incubation (Fig. 4A). Scrambled A $\beta$ had no significant effect on S880 phosphorylation.

We next investigated the effect of channel blockers (nifedipine, TTX, and SKF) on phosphorylation of GluR2 at S880. We found that $5 \mu \mathrm{M}$ nifedipine sig- nificantly decreased phospho-S880 immunoreactivity both in control incubations (lacking $\mathrm{A} \beta$ ) and the $\mathrm{A} \beta$ treated group (Fig. 4B). Both TTX $(5 \mu \mathrm{M})$ and SKF $(5 \mu \mathrm{M})$ also decreased the phospho-S880 immunoreactivity (Figs. 4C,D). In the same incubations, there was 
no effect of nifedipine, TTX, or SKF on total GluR2 levels. These results demonstrated that calcium channel blockers decrease phosphorylation of S880 but do not block the $\mathrm{A} \beta$-induced increase in phosphorylation of $\mathrm{S} 880$, providing further evidence that the effect of $\mathrm{A} \beta$ is not mediated by nifedipine-, TTX- or SKF-sensitive channels. Finally, to investigate the role of calcium in the phosphorylation of S880 further, we examined the effect of the L-type voltage-gated $\mathrm{Ca}^{2+}$ channel activator Bay $\mathrm{K}$ on the on the level of phospho-S880. We found that Bay $\mathrm{K}(1 \mu \mathrm{M})$ significantly increased the phospho-S880 immunoreactivity (Fig. 4E).

We also examined the effect of $\mathrm{A} \beta$, Bay $\mathrm{K}$, nifedipine, TTX and SKF on the localization of GluR2 by immunofluorescence microscopy (Fig. 5). We first stained cell-surface GluR2 on living cells using an ectodomain specific antibody. Then, the cells were fixed and permeabilized and incubated with the phospho-S880 antibody. Cell-surface GluR2 was detected using an Alexa-488 secondary anti-mouse IgG, whereas antiphospho-S880 was detected using an Alexa-594 antirabbit IgG. Using this method, double labeling immunofluorescence showed that the ectodomain specific N-terminal GluR2 was stained on the surface of cells, whereas the anti-phospho-S880 antibody that recognizes C-terminus produced an intracellular labeling pattern (Fig. 5). Cell-surface total GluR2 did not colocalize with phospho-S880 immunoreactivity (Fig. 5). We found that $1 \mu \mathrm{M} \mathrm{A} \beta_{40}$ or $1 \mu \mathrm{M}$ Bay $\mathrm{K}$ significantly decreased the ratio of cell-surface GluR2 immunofluorescence to phospho-S880 immunofluorescence, compared with controls (Fig. 5). On the other hand, $5 \mu \mathrm{M}$ nifedipine, $5 \mu \mathrm{M}$ TTX, and $5 \mu \mathrm{M}$ SKF significantly increased this ratio. Thus, the immunofluorescence results confirmed the results of the biochemical studies and supported the view that the phosphorylation of GluR2 at S880 is regulated by the level of $\left[\mathrm{Ca}^{2+}\right]_{i}$.

\section{GFX decreases phosphorylation of GluR2 and blocks A $\beta$-induced decrease in cell-surface GluR2}

$\mathrm{S} 880$ in GluR2 is phosphorylated by protein kinase $\mathrm{C} \alpha(\mathrm{PKC} \alpha)$, which, in turn, can be activated by calcium $[14,15]$. To elucidate the role of PKC on $\mathrm{A} \beta$ induced phosphorylation of GluR2 at S880 and on the level of cell-surface GluR2, we examined the effects of GFX, a well-characterized PKC inhibitor [22]. We found that $10 \mathrm{nM}$ GFX significantly decreased phosphorylation of GluR2 at S880 and increased cellsurface GluR2, compared with controls (Fig. 6A). GFX also suppressed phosphorylation of S880 in the presence of $\mathrm{A} \beta$. GFX increased the level of cellsurface GluR2, both in the presence and absence of A $\beta$ (Fig. 6A). Furthermore, we found that $10 \mathrm{nM} \mathrm{GFX}$ completely suppressed an increase in phospho-S880 induced by $1 \mu \mathrm{M}$ Bay $\mathrm{K}$, and significantly increased the level of cell-surface GluR2, compared with Bay K treatment alone (Fig. 6B). These results suggest that GFX is able to block the effects of $\mathrm{A} \beta$ and Bay $\mathrm{K}$ on phospho-S880 and on the level of cell-surface GluR2.

To confirm the results of the western blot experiments, we measured cell-surface GluR2 and phosphoS880 by immunofluorescence microscopy. We found that $10 \mathrm{nM}$ GFX significantly increased the ratio of surface GluR2 to phospho-S880 both in control and in A $\beta$ and Bay K groups (Fig. 7). Therefore, the results from immunofluorescence experiments confirmed the results from the biotin-labeling experiments. Taken together, the results support the view that $\mathrm{A} \beta$ increases phospho-S880 by activating PKC.

\section{DISCUSSION}

AMPARs are involved in synaptic plasticity and memory formation $[7,8]$. Recent studies have shown that both the number of AMPARs and their activity are decreased in transgenic AD model mice [9-12]. Previously, studies have shown that $\mathrm{A} \beta$ can remove the AMPAR subunits GluR1 and GluR2 from the cell surface [12]. However, the mechanism by which this occurs is unclear. The present study confirms that $\mathrm{A} \beta$ downregulates cell-surface AMPARs and supports the view that this effect is due to phosphorylation of S880 on GluR2. Resende and colleagues [23] previously reported that an $\mathrm{A} \beta$ peptide $\left(\mathrm{A} \beta_{25-35}\right)$ decreased the total level of GluR2. As $\mathrm{A} \beta_{25-35}$ perturbed calcium homeostasis, this study also supports the idea that calcium may be involved in the dysfunction of AMPA receptors induced by $\mathrm{A} \beta$.

We hypothesized that calcium ion influx induced by $\mathrm{A} \beta$ and phosphorylation of $\mathrm{S} 880$ on GluR2 may be involved into the effects of $\mathrm{A} \beta$ on AMPAR levels and distribution. $\mathrm{Gu}$ and coworkers [13] found that $\mathrm{A} \beta$ impaired GluR1 trafficking and downscaled AMPARs currents by reducing CaMKII. Recently, inhibition of calcineurin, which is stimulated by calcium, was found to prevent endocytosis of AMPAR [24]. In the present study, we found that $\mathrm{A} \beta$ increased phosphorylation of $\mathrm{S} 880$ on GluR2 and also increased $\left[\mathrm{Ca}^{2+}\right]_{i}$. Similar to the effects of $\mathrm{A} \beta$, an activator of calcium channels (Bay $\mathrm{K}$ ) decreased cell-surface GluR2, and increased phos- 

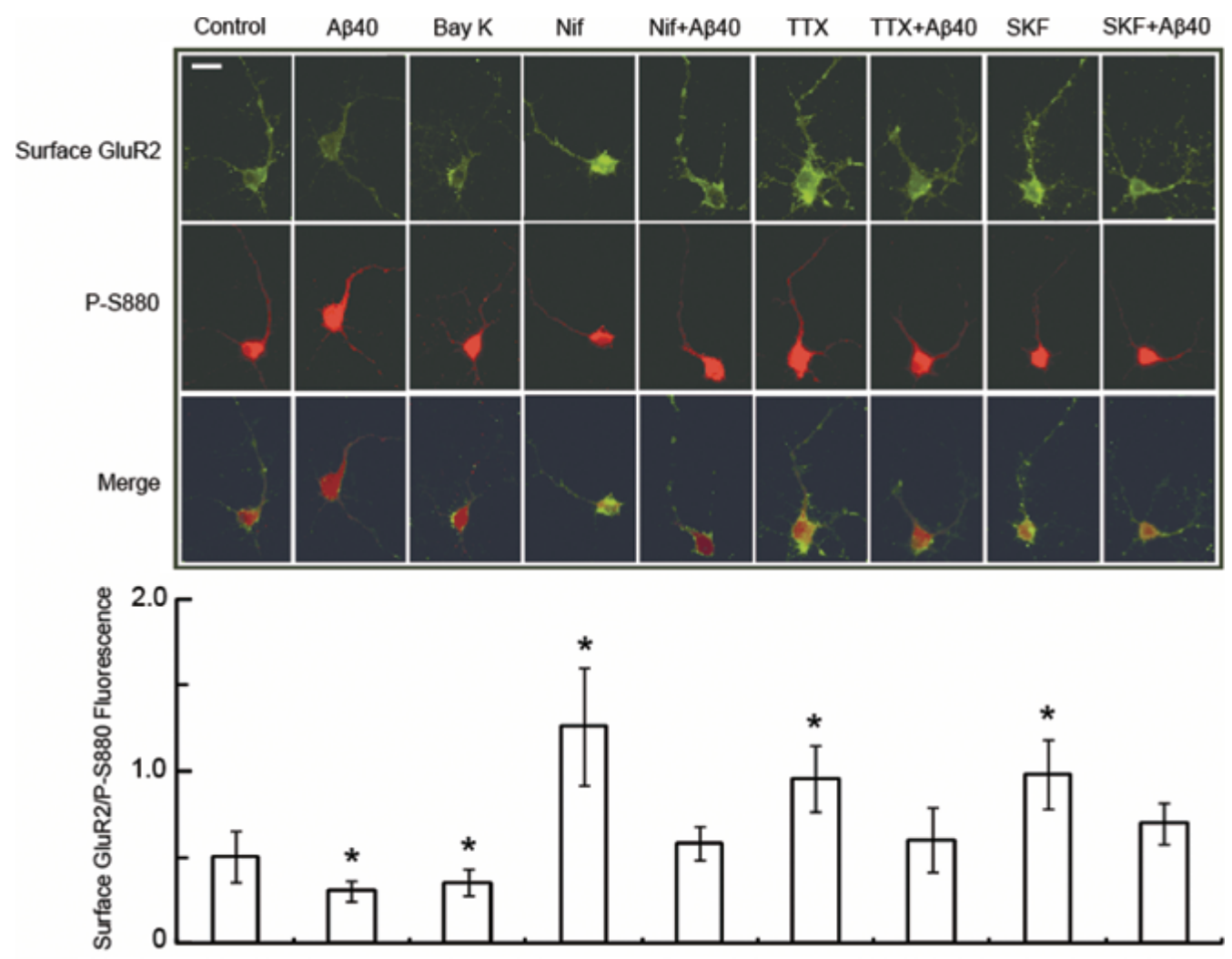

Fig. 5. $\mathrm{A} \beta_{40}(1 \mu \mathrm{M})$ and Bay $\mathrm{K}(1 \mu \mathrm{M})$ decrease the ratio of cell-surface GluR2 to phospho-S880 in hippocampal neurons. Figure shows double immunofluorescence micrographs of cells in which cell-surface GluR2 (Surface GluR2) immunoreactivity was labeled with an anti-mouse Alexa 488 antibody and phospho-S880 immunoreactivity was labeled with an anti-rabbit Alexa 594 antibody. Figure also shows quantitation of fluorescence intensity ( $n=10$ neurons). Nifedipine $(5 \mu \mathrm{M})$, TTX $(5 \mu \mathrm{M})$, and SKF $(5 \mu \mathrm{M})$ significantly increased the ratio of cell-surface GluR2 to phospho-S880 immunofluorescence $\left({ }^{*} p<0.05\right.$, compared with control). Scale bar $=20 \mu \mathrm{m}$.
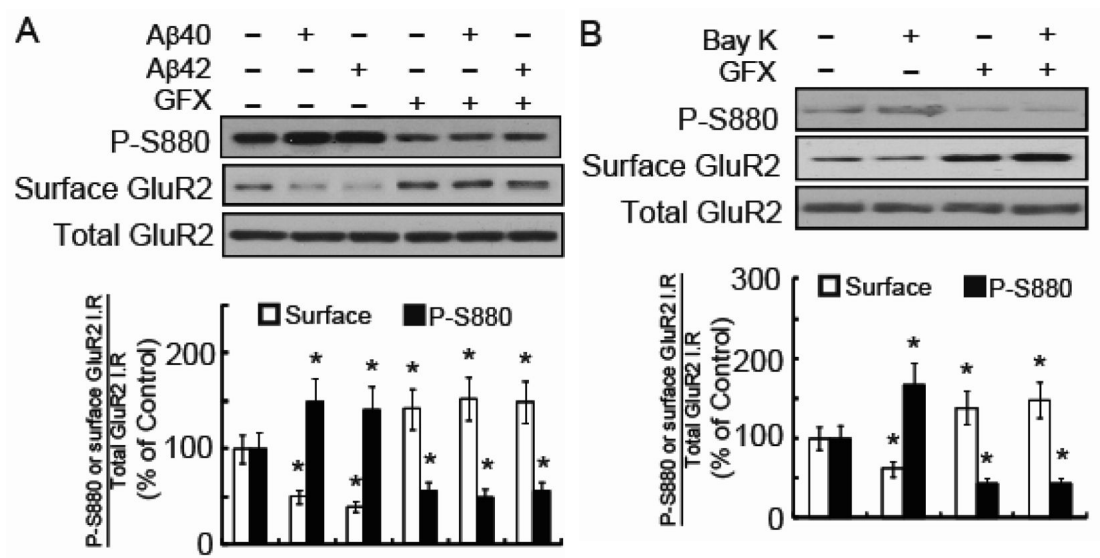

Fig. 6. The PKC inhibitor GFX blocks the decrease in cell-surface GluR2 and the increase in phospho-S880 induced by A $\beta$ (A) and Bay K (B). Figure shows representative western blots of phospho-S880 (P-S880), cell-surface GluR2, and total GluR2 immunoreactivity (I.R.) as well as quantitation of immunoreactive bands ( $n=6$ independent incubations, $\left.{ }^{*} p<0.05\right)$. A) GFX (10 nM) significantly increased cell-surface GluR2 and decreased phospho-S880. Furthermore, GFX blocked a decrease in surface GluR2 and an increase in the phospho-S880 induced by A $\beta$ ( $n=$ 6). B) Bay $\mathrm{K}(1 \mu \mathrm{M})$ significantly increased phospho-S880 and decreased cell-surface GluR2, and $10 \mathrm{nM}$ GFX blocked this effect $\left({ }^{*} p<0.05\right.$, compared with control). 


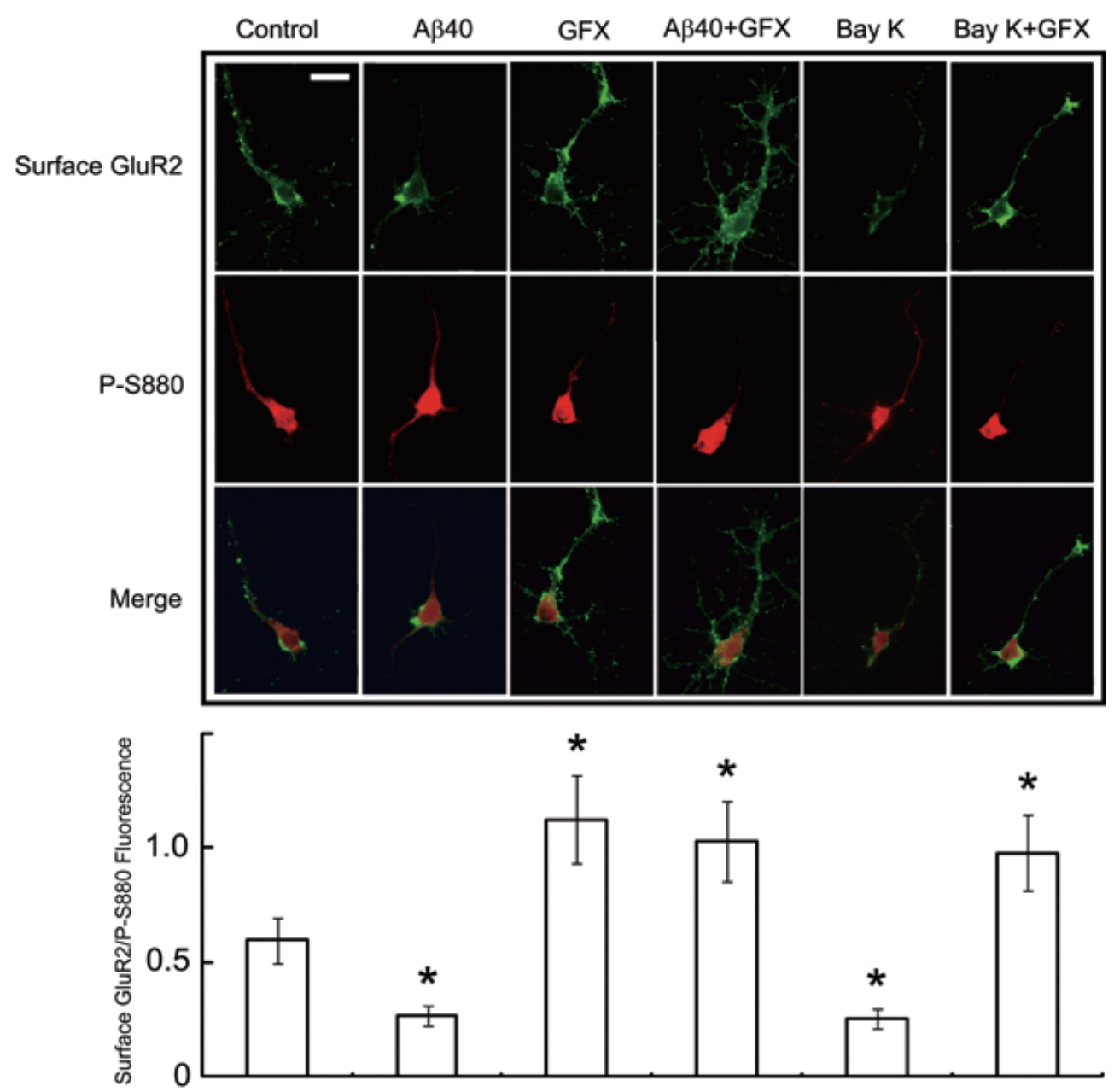

Fig. 7. The PKC inhibitor GFX blocks a decrease in the ratio of cell-surface GluR2 immunofluorescence to phospho-S880 immunofluorescence in hippocampal neurons induced by $\mathrm{A} \beta$ and Bay $\mathrm{K}$. $\mathrm{A} \beta_{40}(1 \mu \mathrm{M})$ and Bay $\mathrm{K}(1 \mu \mathrm{M})$ significantly decreased the ratio of cell surface GluR2 immunofluorescence to phospho-S880 immunofluorescence on hippocampal neurons, and $10 \mathrm{nM}$ GFX significantly increased this ratio. Figure shows double immunofluorescence micrographs of cells in which cell-surface GluR2 (Surface GluR2) immunoreactivity was labeled with an anti-mouse Alexa 488 antibody and phospho-S880 immunoreactivity was labeled with an anti-rabbit Alexa 594 antibody. Figure also shows quantitation of fluorescence intensity ( $n=10$ neurons). GFX blocked the decrease in the ratio of cell-surface GluR2 immunofluorescence to phospho-S880 immunofluorescence induced by A $\beta$ and Bay K. $\left({ }^{*} p<0.05\right.$, compared with control). Scale bar $=20 \mu \mathrm{m}$.

phorylation of S880 of GluR2 and $\left[\mathrm{Ca}^{2+}\right]_{i}$. In contrast, blockers of $\mathrm{Ca}^{2+}$ channels increased cell-surface GluR2, decreased S880 phosphorylation and $\left[\mathrm{Ca}^{2+}\right]_{i}$, Finally, we found that an inhibitor of PKC could block the effects of $\mathrm{A} \beta$ and Bay $\mathrm{K}$ on GluR2 and calcium. Taken together, these data demonstrate that $\mathrm{A} \beta$ decreases the amount of AMPARs on the cell surface by increasing phosphorylation of S880 on the GluR2 subunit.

The mechanisms of calcium influx induced by $\mathrm{A} \beta$ in hippocampal neurons are still unclear. In our studies, we used three different types of channel blockers in the present experiments: an L-type voltage-gated calcium channel blocker (nifedipine), a voltage-gated sodium channel blocker (TTX) and a non-selective cation channel blocker (SKF). All three calcium channel blockers decreased $\left[\mathrm{Ca}^{2+}\right]_{i}$ and S880 phosphorylation and increased cell-surface GluR2 when incubations were performed with $\mathrm{A} \beta$. However, the blockers equally well decreased $\left[\mathrm{Ca}^{2+}\right]_{i}$, phosphorylation of S880 and increased cell-surface GluR2 irrespective of whether $A \beta$ was present. Therefore, the results suggest that while calcium ion influx is important for the effect on cellsurface GluR2, the effect of $\mathrm{A} \beta$ is not directly mediated by L-type voltage-gated calcium channels, voltage- 
gated sodium channels or SKF-sensitive non-selective cation channels.

It is generally believed that $\mathrm{A} \beta$-induced calcium dysregulation is a critical step on impairing neuronal function in AD [2]. However, the mechanism by which calcium dysregulation may cause neuronal dysfunction is unclear. Our present study shows that calcium influx decreases the number of AMPARs on the cell surface. As AMPARs are key mediators of synaptic plasticity [7, $8]$, this suggests that the effects of $\mathrm{A} \beta$ on AMPARs are important for understanding $\mathrm{A} \beta$-induced cognitive dysfunction.

AMPARs are assembled as heterotetramers. GluR2 is the most common subunit in heterotetramic AMPARs [7]. The presence of GluR2 can prevent excitatory neurotoxicity because receptors containing GluR2 are impermeable to calcium [7]. Phosphorylation of S880 controls the balance of intracellular and cellsurface GluR2. Phosphorylation of S880 induces endocytosis of GluR2 and results in removal of GluR2 from the cell surface. It has been reported that $\mathrm{PKC} \alpha$, which belongs to conventional PKCs, is activated by calcium [15], and that the enzyme can phosphorylate S880 [16,17]. In the present study, we found that a PKC inhibitor blocked an $\mathrm{A} \beta$-induced increase in $\mathrm{S} 880$ phosphorylation. The PKC inhibitor also blocked a decrease in cell-surface GluR2 induced by $\mathrm{A} \beta$ and the calcium channel activator Bay K. Therefore, our study strongly suggests that PKC mediates phosphorylation of $\mathrm{S} 880$ induced by $\mathrm{A} \beta$.

As AMPARs are important for LTP [6], A $\beta$-induced activation of PKC and phosphorylation of S880 might contribute to A $\beta$-induced inhibition of LTP [25]. However, the importance of this pathway for inhibiting LTP is not clear. For example, in addition to its action on AMPARs, PKC is known to stimulate LTP [26]. As PKC phosphorylates many different protein substrates, activation of PKC has many complex effects on signaling which are independent of AMPAR recycling. Furthermore, the effects of $\mathrm{A} \beta$ on LTP are likely to be mediated by mechanisms which are entirely independent of S880 phosphorylation.

In conclusion, our study suggests that $\mathrm{A} \beta$-induced calcium entry leads to a decrease in cell-surface AMPARs by increasing phospho-S880 of GluR2. While this pathway will undoubtedly contribute to $\mathrm{A} \beta$ mediated effects on synaptic signaling, it is likely that activation of other pathways will also be important. Identification of these other pathways will require further study.

\section{ACKNOWLEDGMENTS}

This research was supported by project grants to DHS from the National Health and Medical Research Council of Australia.

Authors' disclosures available online (http://www.jalz.com/disclosures/view.php?id=414).

\section{REFERENCES}

[1] Walsh DM, Selkoe DJ (2004) Deciphering the molecular basis of memory failure in Alzheimer's disease. Neuron 44, 181193.

[2] Small DH, Gasperini R, Vincent AJ, Hung AC, Foa L (2009) The role of $\mathrm{A} \beta$-induced calcium dysregulation in the pathogenesis of Alzheimer's disease. J Alzheimers Dis 16, 225-233.

[3] Hu M, Waring JF, Gopalakrishnan M, Li J (2008) Role of GSK-3 $\beta$ activation and $\alpha 7 \mathrm{nAChRs}$ in $\mathrm{A} \beta$ (1-42)-induced tau phosphorylation in PC12 cells. J Neurochem 106, 1371-1377.

[4] Otth C, Concha II, Arendt T, Stieler J, Schliebs R, González-Billault C, Maccioni RB (2002) A $\beta$ PP induces cdk5-dependent tau hyperphosphorylation in transgenic mice Tg2576. J Alzheimers Dis 4, 417-430.

[5] Sperling RA, Laviolette PS, O'Keefe K, O'Brien J, Rentz DM, Pihlajamaki M, Marshall G, Hyman BT, Selkoe DJ, Hedden T, Buckner RL, Becker JA, Johnson KA (2009) Amyloid deposition is associated with impaired default network function in older persons without dementia. Neuron 63, 178-188.

[6] Kullmann DM, Lamsa KP (2007) Long-term synaptic plasticity in hippocampal interneurons. Nat Rev Neurosci 8, 687-699.

[7] Shepherd JD, Huganir RL (2007) The cell biology of synaptic plasticity: AMPA receptor trafficking. Annu Rev Cell Dev Biol 23, 613-643.

[8] Kessels HW, Malinow R (2009) Synaptic AMPA receptor plasticity and behavior. Neuron 61, 340-350.

[9] Carter TL, Rissman RA, Mishizen-Eberz AJ, Wolfe BB, Hamilton RL, Gandy S, Armstrong DM (2004) Differential preservation of AMPA receptor subunits in the hippocampi of Alzheimer's disease patients according to Braak stage. Exp Neurol 187, 299-309.

[10] Chang EH, Savage MJ, Flood DG, Thomas JM, Levy RB, Mahadomrongkul V, Shirao T, Aoki C, Huerta PT (2006) AMPA receptor downscaling at the onset of Alzheimer's disease pathology in double knockin mice. Proc Natl Acad Sci U S A 103, 3410-3415.

[11] Parameshwaran K, Dhanasekaran M, Suppiramaniam V (2008) Amyloid $\beta$ peptides and glutamatergic synaptic dysregulation. Exp Neurol 210, 7-13.

[12] Hsieh H, Boehm J, Sato C, Iwatsubo T, Tomita T, Sisodia S, Malinow R (2006) AMPAR removal underlies A $\beta$-induced synaptic depression and dendritic spine loss. Neuron 52, 831843.

[13] Gu, Z, Liu W, Yan Z (2009) $\beta$-Amyloid impairs AMPA receptor trafficking and function by reducing $\mathrm{Ca}^{2+} /$ calmodulindependent protein kinase II synaptic distribution. J Biol Chem 284, 10639-10649.

[14] Jiang J, Suppiramaniam V, Wooten MW (2007) Posttranslational modifications and receptor-associated proteins in AMPA receptor trafficking and synaptic plasticity. Neurosignals 15, 266-282. 
[15] Perez JL, Khatri L, Chang C, Srivastava S, Osten P, Ziff EB (2001) PICK1 targets activated protein kinase C $\alpha$ to AMPA receptor clusters in spines of hippocampal neurons and reduces surface levels of the AMPA-type glutamate receptor subunit 2. J Neurosci 21, 5417-5428.

[16] Chung HJ, Xia J, Scannevin RH, Zhang X, Huganir RL (2000) Phosphorylation of the AMPA receptor subunit GluR2 differentially regulates its interaction with PDZ domain-containing proteins. J Neurosci 20, 7258-7267.

[17] Brewer GJ (1995) Serum-free B27/neurobasal medium supports differentiated growth of neurons from the striatum, substantia nigra, septum, cerebral cortex, cerebellum, and dentate gyrus. J Neurosci Res 42, 674-683.

[18] Stellwagen D, Beattie EC, Seo JY, Malenka RC (2005) Differential regulation of AMPA receptor and GABA receptor trafficking by tumor necrosis factor- $\alpha$. $J$ Neurosci $25,3219-3228$.

[19] Abramoff MD, Magelhaes PJ, Ram SJ (2004) Image processing with Image J. Biophotonics International 11, 36-42.

[20] Lu W, Man H, Ju W, Trimble WS, MacDonald JF, Wang, YT (2001) Activation of synaptic NMDA receptors induces membrane insertion of new AMPA receptors and LTP in cultured hippocampal neurons. Neuron 29, 243-254.

[21] Takahashi A, Camacho P, Lechleiter JD, Herman B (1999) Measurement of intracellular calcium. Physiol Rev 79, 10891125 .

[22] Toullec D, Pianetti P, Coste H, Bellevergue P, Grand-Perret
T, Ajakane M, Baudet V, Boissin P, Boursier E, Loriolle F, Duhamel L, Charon, D, Kirilovsky J (1991) The bisindolylmaleimide GF $109203 \mathrm{X}$ is a potent and selective inhibitor of protein kinase C. J Biol Chem 266, 15771-15781.

[23] Resende R, Pereira C, Agostinho P, Vieira AP, Malva JO, Oliveira CR (2007) Susceptibility of hippocampal neurons to $\mathrm{A} \beta$ peptide toxicity is associated with perturbation of $\mathrm{Ca}^{2+}$ homeostasis. Brain Res 1143, 11-21.

[24] Zhao WQ, Santini F, Breese R, Ross D, Zhang XD, Stone DJ, Ferrer M, Townsend M, Wolfe AL, Seager MA, Kinney GG, Shughrue PJ, Ray WJ (2010) Inhibition of calcineurinmediated endocytosis and $\alpha$-amino-3-hydroxy-5-methyl-4isoxazolepropionic acid (AMPA) receptors prevents amyloid $\beta$ oligomer-induced synaptic disruption. J Biol Chem 285, 7619-7632.

[25] Shankar GM, Li S, Mehta TH, Garcia-Munoz A, Shepardson NE, Smith I, Brett FM, Farrell MA, Rowan MJ, Lemere CA, Regan CM, Walsh DM, Sabatini BL, Selkoe DJ (2008) Amyloid- $\beta$ protein dimers isolated directly from Alzheimer's brains impair synaptic plasticity and memory. Nat Med 14, 837-842.

[26] Galván EJ, Cosgrove KE, Mauna JC, Card JP, Thiels E, Meriney SD, Barrionuevo G (2010) Critical involvement of postsynaptic protein kinase activation in long-term potentiation at hippocampal mossy fiber synapses on CA3 interneurons. $J$ Neurosci 30, 2844-2855. 